\title{
NOT SEEING THE PEOPLE FOR THE FOREST Thalland's Program of Reforestation by Forced Eviction
}

\author{
Dave Hubbel and Noel Rajesh
}

Thailand's Royal Forestry Department (RFD) and the Royal Thai Army are planning to evict or redistribute the land holdings of over ten million people from the country's National Forest Reserves to enable Thai and foreign corporations to lease land for fast-growing tree plantations, mostly of Eucalyptus camaldulensis. These plantationswill beleased and planted under the auspices of the National Forest Policy as commercial reforestation and harvested to provide raw material for the country's pulp and paper industry. The main obstacle to the RFD's plans for 30000 square kilometres of eucalyptus plantations is opposition from over one million farming families living in village communities located inside the reserves. ${ }^{1}$

Khor Jor Kor, ${ }^{2}$ as the eviction program is known in Thailand, is a "response to the national forest policy ... [whereby] forests in the country will be saved and expanded," according to Major General Vimol Wattanavanit, the Army's Deputy Supreme Commander. ${ }^{3}$ The 1985 National Forest Policy mandates the conservation of natural forest covering twenty-five percent of Thailand's land area and commercial reforestation by the private sector and state agencies to establish economic forests of fast-growing tree crops covering fifteen percent of the country.

Village leaders from all regions of Thailand are opposing the Forestry Department's plans for eucalyptus plantations and KhorJor Kor. According to Buddhist monk Pra Paisal Wisalo, an advocate of forest conservation:

Dave Hubbel is affiliated with the Faculty of Environmental Studies, York University, Toronto, and is working with a Thai environmental NGO.

Noel Rajesh works with a Thai Environmental NGO
The push for eucalyptus plantations and the Khor Jor Kor eviction programme are in one and the same package. The evictions are the culmination of the conflict [between villagers and the RFD]. The authorities resorted to force in order to get the land they need for their profit-making commercial plantation scheme.

The villagers' contend that Khor Jor Kor will only provide financial benefit for the RFD and the pulp and paper industry a claim supported by the vast areas of land to be cleared of villages. In

\section{"The destruction of village people's means of livelihood by agencies of the Thai state reveals its position that villagers are expendable in the interest of the country's present direction of economic development."}

Thailand's northeastern region, the RFD and the Army have targeted 250,000 families living in 2,500 village communities that the Forestry Department contends are encroaching on 22530 square kilometres of protected forest land in 352 forest reserves. The RFD and the Army have begun resettling these families on 5920 square kilometres of land. Another 1760 square kilometres are being cleared of villages to make way for infrastructure projects. The remaining 14720 square kilometres are to be commercially reforested, mostly with eucalyptus.

The Forestry Department claims that eucalyptus plantations constitute "forest." In fact, a monoculture crop of eucalyptus is completely different from a natural forest ecosystem; the plantation destroys biological diversity and villagers' means of livelihood. Since 1985, approximately 1100 square kilometres of eucalyptus plantation has replaced or damaged farmland, fruit orchards, communal grazing areas and community-managed natural forests. Villagers say that eucalyptus exhausts the soil, disrupts local water regimes and is useless as livestock fodder or fuelwood. Native tree species, fruit trees, mushrooms and food crops do not grow in eucalyptus plantations. As for animals, villagers point out that even red ants do not inhabit eucalyptus plantations.

The Forestry Department also claims that villages in the reserves are responsible for deforestation throughout Thailand. But some of the village communities the RFD labels as 'encroachers' were established decades before the RFD delineated the boundaries of the Reserves in the late 1960s. These villages and other communities that settled in the Reserves after delineation, have traditions or community rules that conserve their community forests. Several of the village communities are known throughout Thailand for their efforts to conserve natural forest and protect it from illegal loggers. The forests and woodlots of these communities provide natural forest products, including mushrooms, firewood, building materials and livestock fodder. The forests' native tree species and flora are habitat for birds, insects and small mammals. This forested land may also serve as an abode for spirits of place. The natural forest products and the cultural significance of the forest are essential for the survival of people living on the margins of Thailand's market economy. In effect, the 
Forestry Department could destroy village models of ecologically sustainable human-forest coexistence. Not surprisingly, villagers stridently oppose the Forestry Department's efforts to exercise control over the natural environment.

Village people's opposition to Khor Jor Kor is also due to their knowledge of the program's most obvious shortcomings. Villagers know from personal experience that "land suitable for agricultural use has now almost completely been utilized." In Northeast Thailand, the RFD expects to resettle or redistribute 250,000 families on an area of land onequarter the size of that from which they once sustained themselves. Of this area, land suitable for agriculture is often already owned and farmed by other villages. ${ }^{6}$ In fact, a recent study of villagers displaced by a private company's eucalyptus plantation found that a few people became plantation workers while the rest were forced to clear forest for farmland or migrate to the slums of Bangkok. ${ }^{7}$ Villagers are also aware of the hardship encountered by people evicted by the Army - crops have been ploughed under only weeks before harvest; ${ }^{8}$ soldiers have threatened and beaten villagers resisting eviction.9 Delays in distribution of new land has made some evicted villagers dependent on a monetary compensation equivalent to U.S.\$80 and a package of one and a half sacks of rice and canned fish produced in 1982. ${ }^{10}$

The Khor Jor Kor program reflects the Royal Forestry Department's policy resolution that the interests of Thailand's pulp and paper industry are more important than conservation of the environment and the means of livelihood for ten million Thai citizens. The destruction of village people's means of livelihood by agencies of the Thai state reveals its position that villagers are expendable in the interest of the country's present direction of economic development. The Forestry Department's program of eviction and land redistribution is evidence of the growing intensity of the conflict between state agencies and village people over control of Thailand's environment and its dwindling natural resources.

\section{References}

1. The Royal Forestry Department's Office for Promotion of Private Forestry Plantations predicts eucalyptus plantations will eventually cover 30000 square kilometres of Thailand, Banthuek Thurakit (15-18May 1989), as quoted in Lohmann, L. "Commercial Tree Plantations in Thailand: Deforestation by Any Other Name," The Ecologist 20, 1 (January / February 1990).

2. The official name of the eviction programme is Land Distribution Program for the Poor Living in Degraded Forest Reserves.

3. Malee Traisawasdichai, "An Unsettling Resettlement," The Nation September 1991).

4. Sanitsuda Ekachai, "Torn from the Land: How Tree-Planting Uproots Whole Villages," in Bangkok Post (23 February 1992).

5. Thai Development Research Institute, Thailand Natural Resources Profile (Bangkok, 1987): 19.

6. Villagers have been resettled to land exhausted by banana and sugarcane plantations (see Mangkorn Tengprawat and Anutra na Thalang, "Poor Farm Community Evicted as Year Dawns," Bangkok Post (13 January, 1992)). Villagers have also been resettled on land being used by other farmers (see Atiya Achakulwisut, "Homesteading on Neighbours' Land," Bangkok Post [1 October 1991]).

7. Sayamon Kaiyurawong, unpublished manuscript, Union for Civil Liberties (Bangkok, 1990). The study examined the effects of the Suan Kitti eucalyptus plantation on Laem Khao Chan village, Phanom Sarakham district, Chachoengsao Province.

8. "Unprecedented Level of Violence in Pakham," The Nation (18 September 1991).

9. "Unprecedented level of Violence in Pakham," The Nation (18 September 1991).

10. Achaculwisut, Atiya, "Homesteading on Neighbour's Land," Bangkok Post (1 October 1991): 7.

Refuge is now published ten times a year, Founded in 1980.
CONFERENCE/CALL FOR PAPERS

GENDER ISSUES LND REFUGES: Implicartons For Dovolopmont

The Centre for Refugee Studies and the Centre for Feminist Research at

York University will be hosting a

conference in May 1993 focusing on

Gender Issues And Refugees:

Implications For Development.

A primary objective of the conference is to establish a deeper understanding of the current research and analyses being undertaken in the field of gender and refugee studies. The conference will embody a North/South feminist perspective on refugee issues. Paper presentations and panel discussions, in either French or English, will address issues of a timely nature, and will stimulate broader cross-cultural analysis in this area.

Abstracts (100 words) are invited from academics, service providers, policy makers, and, particularly, former refugees. Subject areas may include:

- Feminist inquiry and refugee studies

- Cultural issues (in asylum settlement, resettlement, repatriation, reintegration)

- Environment; ethnicity/race; work; political persecution; human rights; the state

- Family reconstitution; health; sexuality; violence

- North/South feminism

Some travel funding will be available for paper presenters and discussants from Africa, Asia, the Middle East, Latin America, and the Caribbean.

Deadline for receipt of the abstracts is December 1, 1992, and should be forwarded to:

Farhana Mather

Conference Coordinator

Centre for Refugee Studies

Suite 322, York Lanes

York University

4700 Keele Street, North York

Ontario, Canada M3J IP3

For registration information, and for inclusion in a subsequent bibliography, please submit your name, address, research interests, precis of published/unpublished research, and/or research in progress. 